\title{
PENINGKATAN KUALITAS PEMBELAJARAN PKn MELALUI MODEL COOPERATIVE LEARNING TIPE NHT DENGAN MEDIA PEMBELAJARAN PADA SISWA KELAS IV SD NEGERI 060898 MEDAN MAIMUN
}

\author{
Derliana Siregar \\ Surel: derlianasiregar@gmail.com
}

\begin{abstract}
ABSTRAK
Penelitian ini bertujuan untuk mendeskripsikan peningkatan kualitas pembelajaran Pkn melalui model Cooperative Learning tipe NHT dengan media pembelajaran pada siswa kelas V SD N 060898 Kecamatan Medan Maimun. Subjek penelitian adalah siswa kelas V SD N 060898 Kecamatan Medan Maimun berjumlah 36 siswa. Adapun indikator keberhasilan tindakan ditandai dengan $\geq 75 \%$ dari jumlah siswa yang mengikuti proses pembelajaran telah memperoleh nilai $\geq 70$. Pada siklus I siswa yang memperoleh nilai $\geq 70$ mengalami peningkatan sebesar $25 \%$ dengan kondisi awal $44 \%$ meningkat menjadi $69 \%$ dan pada siklus II mengalami peningkatan sebesar $28 \%$ menjadi $97 \%$. Nilai rata-rata hasil belajar pada siklus I mengalami peningkatan sebesar 8,75\% dengan kondisi awal 66,53 meningkat menjadi 75,27 dan pada siklus II mengalami peningkatan sebesar $10,97 \%$ menjadi 86,25 .
\end{abstract}

Kata Kunci : Hasil Belajar, Model Cooperative Learning Tipe NHT, Media Pembelajaran

\section{PENDAHULUAN}

Siswa yang masih dibawah Kriteria Ketuntasan Minimal (KKM). pada pembelajaran PKn disebabkan guru belum menggunakan model pembelajaran yang tepat dalam menyampaikan materi dan belum disesuaikan dengan karakter siswa. Hal itu terlihat pada saat kegiatan diskusi kelompok berlangsung hanya beberapa anggota kelompok saja yang memperhatikan dan bertanggung jawab dalam mengerjakan tugas kelompok, tidak semua siswa ikut aktif dalam mengerjakan tugas, sehingga proses diskusi kelompok menjadi kurang optimal karena hanya beberapa anggota kelompok atau siswa saja yang bekerja sedangkan yang lain tidak memperhatikan bahkan tidak mengerti apa yang sedang didiskusikan sampai pembelajaran berakhir. Siswa kurang mempunyai tanggung jawab atas tugas yang diberikan oleh guru.

Selain itu, guru belum menggunakan media pembelajaran yang menarik sehingga siswa kurang termotivasi, bosan dan kurang aktif dalam pembelajaran. Banyak diantara siswa yang kurang memperhatikan saat guru sedang menjelaskan materi, mereka justru mengobrol dan bergurau dengan temannya. Hal itu

SD Negeri 060898 Medan Maimun 
mengakibatkan suasana kelas menjadi ramai dan tidak kondusif.

Salah satu cara untuk mengukur efektivitas pembelajaran adalah melalui evaluasi yang dilihat dari pencapaian KKM, untuk mata pelajaran $\mathrm{PKn}$ di $\mathrm{SD} \mathrm{Hj}$ Isriati Baiturrahman 1 adalah 78. Hasil penilaian evaluasi siswa kelas IV SD 060898 Medan Maimun tahun ajaran 2012/2013 sebanyak tiga kali ulangan harian menunjukkan bahwa 23 siswa dari 29 siswa $(79,3 \%)$ belum mencapai standar KKM. Hanya 6 siswa $(20,7 \%)$ yang nilainya diatas KKM. Pada mata pelajaran PKn, didapatkan bahwa pencapaian nilai terendah 53 dan ketercapaian nilai tertinggi adalah 87. Hasil belajar siswa yang rendah dapat digunakan sebagai indikator bahwa pembelajaran PKn belum berhasil.

Untuk memecahkan masalah tersebut, peneliti berkolaborasi dengan guru kelas menetapkan alternatif penelitian tindakan kelas untuk meningkatkan kualitas pembelajaran PKn melalui model Cooperative Learning tipe Number Head Together (NHT) dengan media $\mathrm{CD}$ pembelajaran. Beberapa hasil penelitian yang memperkuat peneliti untuk melakukan penelitian melalui model Cooperative Learning tipe NHT adalah penelitian yang dilakukan oleh Shelvianita Mugi dengan judul Peningkatan Kualitas Pembelajaran $\quad P K n$ dengan
Menggunakan Model Kooperatif Tipe Number Head Together Berbasis ICT pada Siswa kelas IV SD 060898 Medan Maimun. Hasil penelitian menunjukkan bahwa: (1) Hasil keterampilan guru pada siklus I mendapat skor 24 (cukup), pada siklus II meningkat menjadi 31 (baik) dan pada siklus III meningkat menjadi 35 (sangat baik). (2) Hasil observasi aktivitas siswa pada siklus I mendapat jumlah rata-rata skor 22.9 (cukup), meningkat menjadi 31 (baik) pada siklus II dan 34,7 (sangat baik) pada siklus III. (3) Presentase ketuntasan klasikal pada siklus I sebesar $68,6 \%$ (cukup), siklus II 77,8\% (baik) dan $83,3 \%$ (sangat baik) pada siklus III. Nilai tersebut memenuhi indikator keberhasilan yang telah ditetapkan.

Kondisi ini diperkuat juga dengan penelitian yang dilakukan oleh Ana Eka Prihatiningsih dengan judul Peningkatan Prestasi Belajar Siswa melalui Model Cooperative Learning Tipe Numbered Head Together (NHT) dengan Media CD Pembelajaran pada Mata Pelajaran Pendidikan Kewarganegaraan Kelas IV SD 060898 Medan Maimun. Hasil penelitian ini menunjukkan bahwa dengan menggunakan model Cooperative Learning tipe Numbered Head Together dengan media CD pembelajaran dapat meningkatkan aktivitas guru, aktivitas siswa dan prestasi belajar siswa dalam pelajaran PKn. 
Hasil aktivitas guru menunjukkan bahwa pada siklus I rata-rata skor sebesar 2,8, pada siklus II menjadi 3,3 dan siklus III adalah 3,4. Sedangkan hasil observasi ratarata aktivitas siswa pada siklus I sebesar 2,53 meningkat menjadi 2,86 pada siklus II dan 3,17 pada siklus III. Selain itu prestasi hasil belajar siswa pada siklus I persentase ketuntasan sebesar $65,71 \%$ meningkat pada siklus II dengan persentase $74,29 \%$ dan meningkat lagi menjadi $80 \%$ pada siklus III. Nilai tersebut memenuhi indikator keberhasilan yang telah ditetapkan.

Penelitian lain dilakukan juga oleh Mustafa, dkk (2011) dalam Jurnal PTK Desentralized Basic Education (DBE) 3 dengan judul Penerapan Pembelajaran Kooperatif Model Number Head Together (NHT) untuk Meningkatkan Keaktifan dan Penguasaan Konsep Matematika pada siswa kelas IV MTs Negeri Takalala. Dalam penelitian tersebut, keaktifan siswa menunjukkan bahwa pada siklus I sebesar $49 \%$ meningkat pada siklus II dengan presentase $76,6 \%$. Penguasaan konsep pada siklus I pertemuan ke-1 sebesar $36 \%$ dan pertemuan ke-2 sebesar $60 \%$ meningkat pada siklus II menjadi $75 \%$ pada pertemuan ke-1 dan $83,3 \%$ pada pertemuan ke-2. Hal ini menunjukkan bahwa dalam penggunaan model pembelajaraan Number Head Together (NHT) dapat meningkatkan keaktifan siswa dan penguasaan konsep.

Berdasarkan penelitianpenelitian tersebut, terbukti bahwa terjadi peningkatan kualitas pembelajaran setelah menerapkan Model Cooperative Learning tipe NHT dan penggunaan media CD pembelajaran pada mata pelajaran PKn di Sekolah Dasar. Untuk itu peneliti bersama tim kolaborasi yakin bahwa dalam penelitian yang akan dilakukan dengan judul Peningkatan Kualitas Pembelajaran PKn melalui Model Cooperative Learning tipe NHT dengan Media CD Pembelajaran pada Siswa Kelas IV SD 060898 Medan Maimun. dapat meningkat.

Pembelajaran kooperatif tipe NHT merupakan salah satu tipe pembelajaran kooperatif yang menekankan pada struktur khusus yang dirancang untuk mempengaruhi pola interaksi siswa dan memiliki tujuan untuk meningkatkan penguasaan akademik. Pertama kali dikembangkan oleh Spenser Kagen untuk melibatkan lebih banyak siswa dalam menelaah materi yang tercakup dalam suatu pelajaran dan mengecek pemahaman mereka terhadap isi pelajaran tersebut. Slavin (2010:255) mengungkapkan bahwa menomori orang bersama (Number Head Together) pada dasarnya adalah sebuah varian dari Grup Discussion, pembelokannya yaitu hanya ada satu siswa yang mewakili kelompoknya 
tetapi sebelumnya tidak diberi tahu siapa yang akan menjadi wakil kelompok tersebut. Pembelokan tersebut memastikan keterlibatan total dari semua siswa..

Menurut Lie (2004:59), teknik ini memberikan kesempatan kepada siswa untuk saling membagi-bagikan ide dan mempertimbangkan jawaban yang paling tepat. Selain itu, teknik ini juga mendorong siswa untuk meningkatkan semangat kerjasama mereka. Dalam pembelajaran kooperatif tipe NHT dapat dipastikan seluruh siswa akan terlibat total dalam pembelajaran, hal ini yang menjadi alasan dipilihnya NHT. Model ini juga sangat baik karena memberikan tanggung jawab yang penuh kepada setiap siswa dalam kelompok. Dari ulasan latar belakang tersebut, peneliti bersama tim kolaborasi akan mengadakan penelitian tindakan kelas dengan judul, "Peningkatan Kualitas Pembelajaran PKn melalui Model Cooperative Learning tipe NHT dengan Media CD Pembelajaran pada Siswa Kelas IV SD 060898 Medan Maimun.

\section{METODE PENELITIAN}

Penelitian ini akan dilaksanakan di kelas IV SD 060898 Medan Maimun dengan subjek penelitian siswa dan guru. Siswa kelas IVD berjumlah 28 anak yang terdiri dari 18 siswa laki- laki dan 10 siswa perempuan.
Variabel dalam penelitian ini adalah indikator yang terdapat dalam kualitas pembelajaran meliputi:

1. Keterampilan mengajar guru dalam pembelajaran PKn melalui model Cooperative Learning tipe NHT dengan media CD pembelajaran pada siswa kelas IV SD 060898 Medan Maimun.

2. Aktivitas belajar siswa dalam pembelajaran PKn melalui model Cooperative Learning tipe NHT dengan media $\mathrm{CD}$ pembelajaran pada siswa IV SD 060898 Medan Maimun.

3. Hasil belajar siswa dalam pembelajaran PKn melalui model Cooperative Learning tipe NHT dengan media $\mathrm{CD}$ pembelajaran pada siswa kelas IV SD 060898 Medan Maimun.

Siklus I

1) Perencanaan Langkah yang dilakukan pada tahap ini adalah:

1) Mengidentifikasi Standar Kompetensi (SK) dan Kompetensi Dasar (KD) serta menetapkan indikator mata pelajaran PKn.

2) Menyusun perangkat pembelajaran yang terdiri dari penggalan silabus dan Rencana Pelaksanaan Pembelajaran (RPP) sesuai dengan indikator yang telah ditetapkan melalui langkahlangkah model Cooperative 
Learning tipe NHT dengan materi pokok bahasan yaitu pengertian dan contoh pengaruh globalisasi di berbagai bidang.

3) Membuat media CD pembelajaran tentang pengertian dan contoh pengaruh globalisasi dalam berbagai bidang.

4) Membuat nomor kepala.

5) Menyiapkan sarana penunjang pembelajaran seperti: laptop, LCD proyektor, dan speaker.

6) Menyiapkan lembar observasi untuk mengamati keterampilan guru dan aktivitas siswa serta catatan lapangan.

b. Pengamatan

$\begin{array}{lr}\text { 1) Melakukan } & \text { pengamatan } \\ \text { terhadap } & \text { keterampilan } \\ \text { mengajar } & \text { guru }\end{array}$
pembelajaran $\mathrm{PKn}$ melalui model Cooperative Learning tipe NHT dengan media CD pembelajaran.

2) Melakukan pengamatan terhadap aktivitas siswa dalam pembelajaran PKn melalui model Cooperative Learning tipe NHT dengan media CD pembelajaran.

3) Mencatat dan mendokumentasikan hal-hal penting yang terjadi selama pelaksanaan tindakan. c. Refleksi

1) Mengkaji RPP dan proses pelaksanaan pembelajaran yaitu pada keterampilan guru dan aktivitas siswa pada siklus I.

2) Mengkaji kekurangan dan permasalahan yang muncul dalam pelaksanaan proses pembelajaran pada siklus I, serta mendiskusikan bagaimana cara melakukan perbaikan dengan kolabolator.

3) Menyusun perencanaan tindak lanjut untuk siklus II, dengan mengacu pada siklus I.

Siklus II

Langkah yang dilakukan pada tahap ini adalah:

1. Identifikasi masalah pada siklus I dan penetapan alternatif pemecahan masalah.

2. Mengidentifikasi

Standar

Kompetensi

(SK) dan

Kompetensi Dasar (KD) serta menetapkan indikator mata pelajaran Pendidikan Kewarganegaraan.

3. Menyusun Rencana Pelaksanaan Pembelajaran (RPP) sesuai indikator yang telah ditetapkan melalui langkah-langkah model Cooperative Learning tipe NHT dengan materi pokok bahasan yaitu dampak globalisasi dan sikap dalam menghadapi globalisasi. 
4. Membuat $\mathrm{CD}$ pembelajaran tentang dampak globalisasi dan sikap dalam menghadapi globalisasi.

5. Membuat undian untuk nomor kepala siswa.

6. Menyiapkan sarana penunjang pembelajaran seperti: laptop, LCD proyektor, dan speaker.

7. Menyiapkan lembar observasi untuk mengamati keterampilan guru dan aktivitas siswa serta catatan lapangan.

Menentukan nilai tes individu berdasarkan skor teoritis untuk menentukan penilaian tes individu, peneliti menggunakan Metode Penilaian Acuhan Patokan (PAP) dengan sistem penilaian skala 0-100. Pendekatan Penilaian Acuan Patokan (PAP) disebut juga penilaian dengan norma absolut atau kriteria. Pendekatan PAP berarti membandingkan skor-skor hasil tes peserta didik dengan kriteria atau patokan yang secara absolut/mutlak telah ditetapkan oleh guru (Poerwanti dkk, 2008:6-14).

Adapun langkah-langkah PAP dalam penelitian ini yaitu (Poerwanti dkk, 2008:6-15):

a. Menentukan skor berdasarkan proporsi

Skor $=\mathrm{B} \times 100 \%$ (rumus bila menggunakan skala 0-100)
Keterangan:

$\mathrm{B}=$ banyaknya butir yang dijawab benar (dalam bentuk pilihan ganda) atau jumlah skor jawaban benar pada tiap butir/item soal (pada tes bentuk penguraian).

b. Menentukan batas minimal nilai ketuntasan individual

Nilai ketuntasan adalah nilai yang menggambarkan proporsi dan kualifikasi penguasaan peserta didik terhadap kompetensi yang telah dikontrakkan dalam pembelajaran (Poerwanti dkk, 2008:6-16). Pada penelitian ini batas minimal perolehan siswa adalah 78, karena kriteria ketuntasan minimal pelajaran PKn Kelas IV SD 060898 Medan Maimun. Perhitungan ini harus disesuaikan dengan kriteria ketuntasan belajar siswa SD IV SD 060898 Medan Maimun. Kriteria Ketuntasan Minimal (KKM) Kualifikasi $\geq 78$ Tuntas dan $<78$ Tidak Tuntas (Sumber: KKM PKn Kelas IV SD 060898 Medan Maimun, Tahun Pelajaran 2012/2013).

Analisis data kualitatif digunakan untuk menilai keterampilan guru dan hasil aktivitas siswa melalui model Cooperative Learning tipe NHT dengan media CD. Data kualitatif dipaparkan dalam kalimat yang dipisah-pisahkan menurut kategori untuk memperoleh kesimpulan. Data kualitatif ini 
diperoleh dari pengolahan data yang didapat dari instrument pengamatan keterampilan guru dan instrument pengamatan aktivitas siswa.

Pembelajaran melalui model Cooperative Learning tipe NHT dengan media $\mathrm{CD}$ pembelajaran untuk meningkatkan kualitas pembelajaran PKn pada siswa kelas IV SD 060898 Medan Maimun dikatakan berhasil apabila:

1. Keterampilan guru kelas IV SD 060898 Medan Maimun dalam melaksanakan pembelajaran melalui model Cooperative Learning tipe NHT dengan media $\mathrm{CD}$ pembelajaran minimal baik $(18 \leq$ skor $<27,5)$.

2. Aktivitas siswa kelas IV SD 060898 Medan Maimun dalam melaksanakan pembelajaran melalui model Cooperative Learning tipe NHT dengan media $\mathrm{CD}$ pembelajaran minimal baik $(20 \leq$ skor $<30,5)$.

3. Hasil belajar siswa kelas IV SD 060898 Medan Maimun dalam pembelajaran PKn melalui model Cooperative Learning tipe NHT dengan media $\mathrm{CD}$ pembelajaran mencapai ketuntasan belajar klasikal $\geq 85 \%$ dan individu $\geq 78$.

\section{HASIL DAN PEMBAHASAN}

Penelitian tindakan kelas ini dilaksanakan dalam 3 siklus di kelas IV SD 060898 Medan Maimun. Siklus I dilaksanakan pada tanggal 13
Mei 2013, siklus II dilaksanakan pada tanggal 16 Mei 2013, dan siklus III dilaksanakan pada tanggal 20 Mei 2013. Peneliti akan memaparkan hasil penelitian yang terdiri atas keterampilan mengajar guru, aktivitas belajar siswa, serta hasil belajar dalam pembelajaran PKn melalui model Cooperative Learning tipe NHT dengan media CD pembelajaran. Berikut ini peneliti akan memaparkan hasil penelitian secara lebih rinci pada masing-masing siklus.

Perencanaan Peneliti bersama kolaborator menyusun perencanaan siklus I yaitu sebagai berikut:

1. Mengidentifikasi Standar Kompetensi (SK) dan Kompetensi Dasar (KD) serta menetapkan indikator mata pelajaran PKn.

2. Menyusun perangkat pembelajaran yang terdiri dari penggalan silabus dan Rencana Pelaksanaan Pembelajaran (RPP) sesuai indikator.

Berdasarkan hasil belajar siswa pada mata pelajaran PKn, terdapat peningkatan hasil belajar siswa yang melakukan pembelajaran dengan menggunakan model Cooperative Learning tipe NHT dengan media $\mathrm{CD}$ pembelajaran pada siklus I, siklus II dan siklus III.

Adapun data yang diperoleh sebagai berikut: 


\begin{tabular}{|c|c|c|c|}
\hline Statistik & $\begin{array}{c}\text { Siklus } \\
\text { I }\end{array}$ & $\begin{array}{c}\text { Siklus } \\
\text { II }\end{array}$ & $\begin{array}{c}\text { Siklus } \\
\text { III }\end{array}$ \\
\hline Rata-rata & 57,3 & 68,5 & 81,4 \\
\hline $\begin{array}{c}\text { Nilai } \\
\text { Tertinggi }\end{array}$ & 85 & 90 & 100 \\
\hline $\begin{array}{c}\text { Nilai } \\
\text { Terendah }\end{array}$ & 10 & 37 & 40 \\
\hline Tuntas & 7 & 11 & 20 \\
\hline $\begin{array}{c}\text { Tidak } \\
\text { Tuntas }\end{array}$ & 19 & 17 & 3 \\
\hline $\begin{array}{c}\text { Ketuntasan } \\
\text { klasikal }\end{array}$ & $26,9 \%$ & $39,3 \%$ & $86,9 \%$ \\
\hline
\end{tabular}

Hal ini menunjukkan bahwa ada peningkatan nilai rata-rata kelas pada setiap siklus. Begitu pula dengan perolehan nilai setiap siswa, pada siklus I nilai tertinggi hanya 85 , kemudian meningkat menjadi 90 pada siklus II dan mencapai nilai maksimal yaitu 100 pada siklus III. Sama halnya dengan perolehan nilai tertinggi, perolehan nilai terendah pun mengalami peningkatan, yakni yang hanya mendapatkan nilai 10 pada siklus I, kemudian meningkat menjadi 37 pada siklus II dan menjadi 40 pada siklus III.

Selain itu, peningkatan juga terjadi pada jumlah siswa yang tuntas pada mata pelajaran PKn, yaitu ada 7 siswa pada siklus I, meningkat menjadi 11 siswa pada siklus II dan meningkat lagi menjadi 20 siswa pada siklus III. Oleh sebab itu, jumlah siswa yang tidak tuntas pun mengalami penurunan pada setiap siklus. Ada sebanyak 19 siswa yang tidak tuntas pada siklus I, kemudian menurun menjadi 17 siswa pada siklus II dan akhirnya hanya ada 3 siswa saja yang tidak tuntas pada siklus III. Hal tersebut menunjukan bahwa adanya peningkatan pada ketuntasan belajar siswa secara klasikal. Bisa dilihat dari persentase pencapaian ketuntasan klasikal yaitu sebesar 26,9\% pada siklus I, kemudian meningkat menjadi 39,3\% pada siklus II dan mencapai $86,9 \%$ pada siklus III.

Melihat peningkatan hasil belajar secara signifikan dari siklus I, siklus II dan siklus III membuktikan bahwa melalui model Cooperative Learning tipe NHT dengan media CD pembelajaran akan membawa dampak positif bagi hasil belajar siswa jika dilaksanakan dan diterapkan dengan baik.

Hasil penelitian ini menunjukkan adanya peningkatan kualitas pembelajaran PKn yang meliputi keterampilan guru, aktivitas siswa dan hasil belajar melalui model Cooperative Learning tipe NHT dengan media CD pembelajaran pada siswa kelas IV SD 060898 Medan Maimun. Melalui model Cooperative Learning tipe NHT dengan media CD pembelajaran ini pembelajaran tidak hanya terpusat pada guru (teacher centered), tetapi juga pembelajaran yang terpusat pada siswa (student centered). Guru hanya menjadi fasilitator yang memfasilitasi siswa dalam belajar dan motivator untuk memberikan dorongan dan semangat supaya siswa aktif mengikuti setiap 
langkah-langkah dalam pembelajaran.

Model pembelajaran NHT ini dapat membuat siswa lebih semangat dan bersungguh-sungguh dalam mengikuti proses pembelajaran karena setiap siswa mempunyai tanggung jawab terhadap nomor kepala yang dimilikinya untuk tugas kelompok yang dikerjakannya, sehingga jika dipanggil oleh guru untuk bertanya, menanggapi ataupun memberikan pendapatnya, mereka harus siap. Dengan media CD pembelajaran, penyajian materi menjadi lebih menarik perhatian siswa sehingga mereka lebih termotivasi dalam mengikuti pembelajaran dan lebih memperhatikan penjelasan guru. Hal tersebut membuat suasana di kelas menjadi lebih hidup dan berwarna. Pembelajaran menjadi lebih efektif dan efisien. Selain itu dapat memudahkan siswa untuk mempelajari, memahami dan mendalami materi.

\section{SIMPULAN}

Berdasarkan hasil penelitian dan pembahasan mengenai kualitas pembelajaran pada keterampilan guru, aktivitas siswa, dan hasil belajar siswa dalam pembelajaran $\mathrm{PKn}$ melalui model Cooperative Learning tipe NHT dengan media CD pembelajaran pada siswa kelas IV 060898 Medan Maimun dapat disimpulkan sebagai berikut:
1. Keterampilan guru kelas IV SD 060898 Medan Maimun dalam pembelajaran PKn melalui model Cooperative Learning tipe NHT dengan media $\mathrm{CD}$ pembelajaran meningkat secara bertahap pada tiap siklusnya. Peningkatan tiap siklusnya ditunjukkan dengan jumlah skor keterampilan guru pada pelaksanaan siklus I sebesar 22 dengan persentase $61 \%$ berkategori baik, pada siklus II jumlah skor meningkat menjadi sebesar 29 dengan persentase $80,5 \%$ berkategori sangat baik, dan terjadi peningkatan jumlah skor pada siklus III menjadi sebesar 34 dengan persentase 95\% berkategori sangat baik.

2. Aktivitas siswa kelas IV SD 060898 Medan Maimun dalam pembelajaran PKn melalui model Cooperative Learning tipe NHT dengan media $\mathrm{CD}$ pembelajaran meningkat secara bertahap pada tiap siklusnya. Peningkatan tiap siklusnya ditunjukkan dengan jumlah rata-rata skor aktivitas siswa pada pelaksanaan siklus I sebesar 13,85 dengan persentase $34,5 \%$ berkategori cukup, siklus II jumlah ratarata skor aktivitas siswa meningkat menjadi sebesar 20,07 dengan persentase $50,25 \%$ berkategori baik dan terjadi peningkatan jumlah rata-rata skor pada siklus III menjadi 
sebesar 27,23 dengan persentase $68 \%$ berkategori baik.

3. Hasil belajar siswa kelas IV SD 060898 Medan Maimun dalam pembelajaran PKn melalui model Cooperative Learning tipe NHT dengan media $\mathrm{CD}$ pembelajaran meningkat secara bertahap pada tiap siklusnya. Pada siklus I mendapatkan persentase ketuntasan klasikal siswa sebesar 26,9\% dengan kualifikasi tidak tuntas, kemudian meningkat pada siklus II yaitu menjadi 39,3\% dengan kualifikasi tidak tuntas dan pada siklus III meningkat lagi menjadi $86,9 \%$ dengan kualifikasi tuntas. Hasil penelitian dan pembahasan menjelaskan bahwa terjadi peningkatan keterampilan guru, aktivitas siswa, dan hasil belajar dari siklus I sampai siklus III.

Berdasarkan hasil penelitian yang disimpulkan maka saran yang dapat disampaikan adalah sebagai berikut:

1. Penelitian melalui model Cooperative Learning tipe NHT dengan media $\mathrm{CD}$ pembelajaran ini semoga dapat memberikan kontribusi pada perkembangan ilmu pengetahuan dan teknologi, menjadi bahan kajian serta referensi untuk penelitian selanjutnya, supaya memperoleh hasil yang lebih baik.

2. Guru dapat menggunakan model pembelajaran kooperatif, variatif dan inovatif, yaitu salah satunya adalah model Cooperative Learning tipe NHT dengan dengan media CD pembelajaran dalam pembelajaran PKn maupun pembelajaran lainnya sehingga mampu menciptakan kegiatan belajar mengajar yang menarik dan menyenangkan untuk meningkatkan kualitas pembelajaran.

3. Penelitian melalui model Cooperative Learning tipe NHT dengan media $\mathrm{CD}$ pembelajaran dapat dikembangkan lebih lanjut oleh sekolah dengan harapan penerapan model Cooperative Learning tipe NHT dan pengoperasian media $\mathrm{CD}$ pembelajaran dapat memberikan kontribusi dalam perbaikan pembelajaran di kelas, sehingga dapat meningkatkan mutu sekolah.

\section{DAFTAR RUJUKAN}

Anitah, Sri W, dkk. 2009. Strategi Pembelajaran di SD. Jakarta: Universitas Terbuka.

Arsyad, Azhar. 2011. Media Pembelajaran. Jakarta: PT Raja Grafindo Persada.

Aqib, Zainal, dkk. 2010. Penelitian Tindakan Kelas. Bandung: CV. YRAMA WIDYA. 
Derliana Siregar : Peningkatan Kualitas ..

Arikunto, Suharsimi. 2006. Prosedur Penelitian Suatu Pendekatan Praktik. Jakarta: Rineka Cipta.

Arikunto, Suharsimi, Suhardjono, Supardi. 2008. Penelitian Tindakan Kelas. Jakarta: PT Bumi Aksara.

Baharudin, Esa Nur Wahyuni. 2007. Teori Belajar dan Pembelajaran. Yogyakarta: Arruzz media.

BSNP. 2006. Standar Isi untuk Satuan Pendidikan Dasar dan Menengah, Standar Kompetensi dan Kompetensi Dasar SD/MI. Jakarta: BSNP.

Depdiknas. 2008. Peraturan Menteri Pendidikan Nasional. Jakarta: Direktoral Jenderal Manajemen Pendidikan Dasar dan Menengah.

Depdiknas. $2003 . \quad$ Media Pembelajaran. Jakarta: Direktoral Jenderal Pendidikan Dasar dan Menengah.

Deva. 2012. Aktivitas Siswa. http://devamelodica.com/teoriminat-pada-skripsipendidikandan-daftar-pustaka-minatlengkap. (diunduh pada 14 Februari 2013, 10.00 WIB)

Djamarah, Syaiful Bahri. 2010. Guru dan Anak Didik dalam Interaksi Edukatif. Jakarta: Rineke Cipta.

Hamalik, Oemar. 2001. Proses Belajar Mengajar. Jakarta: Bumi Aksara.
Hamdani. 2011. Strategi Belajar Mengajar. Bandung: Pustaka Setia.

Herrhyanto, dkk. 2008. Statistika Dasar. Jakarta: Universitas Terbuka. 